\title{
COVID-19 Infection in South Korea: Focusing on Age Distribution of Confirmed Cases
}

\author{
Hyunjoo $\mathrm{J}^{1}{ }^{1}$ (D) and Yun-Jung Kang ${ }^{2 *}$ (D) \\ ${ }^{1}$ Department of Preventive Medicine, College of Medicine, Dankook University, Cheonan 31116, Republic of Korea. \\ ${ }^{2}$ Department of Clinical Laboratory Science, Sang-ji University, Wonju 26339, Republic of Korea.
}

\begin{abstract}
A new kind of respiratory infectious disease, COVID-19, which first occurred in Wuhan, China, on December 31st, 2019, has affected all over China. After that, the first case of COVID-19 in South Korea was confirmed on January $20^{\text {th }}, 2020$. Currently, on April $7^{\text {th }}$, the accumulated number of confirmed cases is 10,331 , with 6,694 among them released from quarantine. Age distributions among the confirmed cases shows that patients between $20-29$ occupy the most portion with $27 \%$. The younger generations occupies the highest portion of the confirmed cases. Additionally, as their high infection rate can serve as a risk factor of spreading the disease to their family members, they should actively participate in the prevention of the disease by thorough practice of social distancing. Their participation is expected to serve an important role in ending COVID-19.
\end{abstract}

Keywords: Age Distribution, Confirmed Cases, COVID-19, Social distancing, Younger generation

*Correspondence: Ivpig@naver.com; +82-33-738-8081

(Received: May 02, 2020; accepted: May 08, 2020)

Citation: Joo H, Kang Y, COVID-19 Infection in South Korea: Focusing on Age Distribution of Confirmed Cases. J Pure Appl Microbiol. 2020;14(suppl 1):721-723. doi: 10.22207/JPAM.14.SPL1.08

C The Author(s) 2020. Open Access. This article is distributed under the terms of the Creative Commons Attribution 4.0 International License which permits unrestricted use, sharing, distribution, and reproduction in any medium, provided you give appropriate credit to the original author(s) and the source, provide a link to the Creative Commons license, and indicate if changes were made. 


\section{INTRODUCTION}

After affecting all over China, following the first occurrence on December $31^{\text {st }}, 2019$, in Wuhan, China, a new kind of respiratory infectious disease, COVID-19 is spreading throughout the world, with confirmed cases in Asia, the Americas, and Europe. The Novel Coronavirus, which is a variation of the corona virus family, is named COVID-19 by WHO. Korea Centers for Disease Control and Prevention named it Corona $19^{1}$. The first case of COVID-19 was confirmed on January $20^{\text {th }}, 2020.75 \%$ of novel infectious diseases that have occurred during and after the $20^{\text {th }}$ century are due to viruses, zoonotic viruses derived from wild animals in particular. Unlike other disasters, infectious diseases are born and spread by pathogens such as bacteria and viruses, which are invisible to the human eye ${ }^{2}$. COVID-19 causes characteristic symptoms of high fever, cough, and dyspnea. It is more fearful that the disease can infect other people even during the incubation period; starting from Germany, many countries including Japan have witnessed this phenomenon. The most serious problem of a novel virus infection is that we do not have a cure ${ }^{3}$. Pathogens must be separated from the infected, cultivated, and used for developing a new cure; a process that needs more than a year. In situations where no vaccines and cures exist, a thorough practice of social distancing to prevent infection is the best solution.

The Current situation in South Korea at 00:00 a.m. on April $7^{\text {th }}, 2020$, is as follows (Table 1). The accumulated number of confirmed cases is 10,331 , with 6,694 among them released from quarantine. New confirmed cases are 47 and the total number of deaths is 192. Age distributions among the confirmed cases shows that patients between 20-29 occupy the most portion with $27 \%$. The research done by US CDC also shows that young people's immunity against COVID-19 is below expectation. The hongkong South China Morning Post reported on March $19^{\text {th }}$ that the CDC had surveyed 4,226 US patients who have been infected since the $12^{\text {th }}$ last month and found out that 705 among them, that is, one fifth of them, were between $20-44$ of age. $2-4 \%$ of these patients are in serious conditions. Deborah Bricks, who is the second in charge of the COVID-19 taskforce of the White House, emphasized at a press conference that "data disclosed by the French and Italian governments also show that there are young people who are in serious conditions and under special treatment."

According to a research done on more than 2,000 child COVID-19 patients, most patients showed only mild or ordinary symptoms. However, babies and newborns have also developed into serious cases sometimes ${ }^{4}$. As infectious disease experts emphasize, COVID-19 can infect all age groups. Even though the chance of young COVID-19 patients dying from the disease is very low, it is warned that the disease can damage the lungs and other organs permanently. Even younger generations with stronger immune system are not free from the danger. According to the Central Disease Relief Center's report on April $5^{\text {th }}, 2020$, the total number of serious or higher risk patients

Table 1. Confirmed cases gender, Status by age (00:00, April $7^{\text {th }}$ )

\begin{tabular}{|c|c|c|c|c|c|c|}
\hline \multicolumn{2}{|c|}{ Classification } & \multirow{2}{*}{$\begin{array}{c}\begin{array}{c}\text { Confirmed } \\
\text { cases }\end{array} \\
10,331\end{array}$} & \multirow{2}{*}{$\begin{array}{c}(\%) \\
(100)\end{array}$} & \multirow{2}{*}{$\begin{array}{c}\text { Deaths } \\
192\end{array}$} & \multirow{2}{*}{$\begin{array}{c}(\%) \\
(100)\end{array}$} & \multirow{2}{*}{$\begin{array}{c}\text { Fatality } \\
\text { rate (\%) }\end{array}$} \\
\hline Total & & & & & & \\
\hline \multirow[t]{4}{*}{ Gender } & male & 4,138 & (40.05) & 101 & $(52.60)$ & 2.44 \\
\hline & female & 6,193 & (59.95) & 91 & (47.40) & 1.47 \\
\hline & $80 s \leq$ & 466 & $(4.51)$ & 93 & (48.44) & 19.96 \\
\hline & $70-79 s$ & 689 & $(6.67)$ & 57 & (29.69) & 8.27 \\
\hline \multirow[t]{7}{*}{ age } & $60-69 s$ & 1,304 & (12.62) & 26 & (13.54) & 1.99 \\
\hline & $50-59 s$ & 1,909 & (18.48) & 13 & (6.77) & 0.68 \\
\hline & $40-49 s$ & 1,382 & (13.38) & 2 & (1.04) & 0.14 \\
\hline & $30-39 s$ & 1,092 & (10.57) & 1 & $(0.52)$ & 0.09 \\
\hline & $20-29 s$ & 2,819 & (27.29) & 0 & $(0.00)$ & - \\
\hline & $10-19 s$ & 544 & $(5.27)$ & 0 & $(0.00)$ & - \\
\hline & $0-9 s$ & 126 & (1.22) & 0 & $(0.00)$ & - \\
\hline
\end{tabular}


in South Korea is 81 , with 50 critical patients and 31 serious cases. Among them are a serious patient in 30's and a critical patient in 20's, who are both relatively young. The critical patient in 20 's is now doing OK without using an ECMO but still dependent on the respirator ${ }^{5}$.

Despite the intense social distancing policy by the South Korean government, some adult entertainment establishments such as clubs are crowded with young people milling in. Although the desire to express their youth is a common tendency worldwide, clubs where people contact each other in a closed area are highly dangerous places in which mass infection can occur. Younger citizens can be "quiet spreaders" in this situation. The South Korean government has urged "intense social distancing" policies to be prolonged until April $19^{\text {th }}$, which affects operation of adult entertainment facilities including clubs. When opening, these establishments should follow prevention guidelines, such as obliging mask wearing, distancing clubbers at least $1-2 \mathrm{~m}$ from each other in facilities, checking symptoms such as fever on entry, registering the names of visitors, and placing hand sanitizers. Local government heads are also warned that each establishment would be checked frequently; the clubs are also liable to punishment of suspension, fine, and compensation for damage when they breach the guideline ${ }^{6}$.

Before now, it was a common notion that younger people were relatively safe from COVID-19. However, the younger generations occupies the highest portion of the confirmed cases. Additionally, they cannot be said to be secure as their lungs and other organs can be damaged permanently. Additionally, as their high infection rate can serve as a risk factor of spreading the disease to their family members, they should actively participate in the prevention of the disease by thorough practice of social distancing. Their participation is expected to serve an important role in ending COVID-19. This study would be provided as a basic material about managing confirmed cases and disease prevention in future influx of novel infectious diseases.

\section{ACKNOWLEDGMENTS}

None.

\section{CONFLICT OF INTERESTS}

The listed author(s) declare no conflict of interest in any capacity, including competing or financial.

\section{AUTHORS' CONTRIBUTION}

$\mathrm{HJ}$ and $\mathrm{YJ}$ made contributions to the conception and design and to the acquisition of data. All authors read and approved the final revised manuscript.

\section{FUNDING}

None.

\section{ETHICS STATEMENTS}

This article does not contain any studies with human participants or animals performed by any of the authors.

\section{AVAILABILITY OF DATA}

The datasets used and/or analyzed during the current study are available from the corresponding author on reasonable request.

\section{REFERENCES}

1. Korea Centers for Disease Control and Prevention; 2020 Feb 12 [cited 2020 Apr 7]. Available From:http://ncov.mohw.go.kr/tcmBoardView. do ? brd Id = \&brdGubun $=\&$ dataGubun $=$ \&ncvContSeq=352840\&contSeq=352840\&board_ $\mathrm{id}=140$ \&gubun=BDJ (Korean).

2. Korea Centers for Disease Control and Prevention; 2019 Sep 1 [cited 2020 Apr 7]. Available From: https://www. cdc.go.kr/board.es? $\mathrm{mid}=\mathrm{a} 20501000000 \& \mathrm{bid}=0015 \&$ act=view\&list_no=143387 (Korean).

3. Lee JS, A Study on Improvement of Infectious Disease Control and Prevention Act and System, Seoul. Korea Legislation Research Institute 2018. Available From: http://www.klri.re.kr:9090/handle/2017.oak/7319

4. Yoon CS. "The young man is not invincible to Corona" $20 \%$ of American CDC patients under 44. Seoul Newspaper; 2020 Mar 19 [cited 2020 Apr 7]. Available from: https://news.naver.com/ $\mathrm{main} / \mathrm{read}$. nhn? mode $=\mathrm{LSD} \& \mathrm{mid}=\mathrm{sec} \&$ oid $=$ 081\&aid=0003075153\&sid1=001 (Korean).

5. Kim TH, Um SJ, Lee YS, Seo YB. 'Corona 19' 81 patients with severe or severe illness... Reliance on artificial respiration in 1 of 20s (complementary). News 1; 2020 Apr 5 [cited 2020 Apr 7]. Available from: https://www. news1.kr/articles/?3897075 (Korean).

6. An SJ. "Let's line up for the club despite social distance" Will high-strength sanctions come out?. World Daily; 2020 Apr 7 [cited 2020 Apr 7]. Available from: http://www.segye.com/ newsView/20200407508699?OutUrl=naver (Korean). 